\title{
PRODUCTION PROCESS AND MARKETING SYSTEM OF CUCUMBER: A SOCIOECONOMIC STUDY IN MYMENSINGH DISTRICT OF BANGLADESH
}

\author{
A. Lutfa ${ }^{1}$, F.A. Happy ${ }^{2 *}$ and F. Yeasmin ${ }^{2}$ \\ ${ }^{1}$ Department of Agribusiness and Marketing, Bangladesh Agricultural University, Mymensingh \\ ${ }^{2}$ Department of Agricultural Economics, Bangladesh Agricultural University, Mymensingh,
}

\begin{abstract}
The study was undertaken to evaluate the production process and marketing system of cucumber in Mymesingh district of Bangladesh. Primary data were collected from 50 stakeholders (30 farmers, 7 wholesaler, 7 retailers and 6 local traders) of Phulpur upazila and Mymensingh city. Purposive sampling technique was used to select the producers and convenience sampling was used for selecting the traders. The study revealed that production of cucumber was profitable in the study areas (with benefit cost ratio 1.59). Total marketing cost of cucumber was the highest for local traders (Tk. 2.73 per acre) and lowest for retailers (Tk.1.57per acre).In the study area, six market participants were identified which were producer, local trader, wholesaler, retailer, street seller and consumer. Gross and net marketing margin were the highest for retailers $(4.25 \mathrm{Tk} . / \mathrm{kg}$ and $2.65 \mathrm{Tk} . / \mathrm{kg}$, respectively). The study identified two cucumber marketing channels in Phulpur upazila and five in Mymensingh city. The seasonal price index of cucumber was the highest in the month of October (135.67) which indicated that price of cucumber in this month was 35.67 percent higher than average price and the lowest was in May (60.62). The result implied that price in this month was 39.38 per cent less than average price. The findings of this study about production, marketing function and seasonal price will help farmers and intermediaries involved with cucumber production and marketing to improve cucumber business.
\end{abstract}

Keywords: Production; Marketing; Cucumber; Bangladesh.

\section{INTRODUCTION}

Cucumber is a popular cultivated plant in the gourd family Cucurbitaceae that managed to captivate our attention from the moment it appeared in ancient India. Since that pivotal moment over 4000 years ago, cucumber was spread beyond Indian borders, moved through Ancient Greece, Rome, Europe, New World, China, and

* Corresponding author: fardoushappy83@gmail.com 
eventually becoming fourth most widely cultivate vegetable in the world. This journey was filed with golden periods when they were viewed as integral parts of many culture's cuisines, and sometimes they were treated as bringers of disease. Agricultural is the dominant sector of the Bangladesh economy and growth and stability of Bangladesh depends largely on the growth of agriculture. About 60$75 \%$ people of Bangladesh fully and partially depend on Agricultural sector. In Bangladesh about 22286 acres of land is under cucumber cultivation and total production is approximately 54854 metric tons (BBS, 2014). Thus, the average yield of cucumber is about 55 quintal per hectare which is very low compared to those of other countries of the world. It has scope to decrease this quantity of import but the fact is the absence of high yielding cultivars of cucumber and the improved method of cultivation. Since the soil and climatic condition of Bangladesh are suitable to cultivate cucumber, it is expected the selection of high yielding varieties will augment the yield considerably. Indeed there is a vast scope to increase cucumber production with the introduction of selected high yielding varieties (Siful, 2008).

Cucumber plays an important role to meet the vegetable shortage during the scarce period, which ultimately helps to improve the malnutrition problem in Bangladesh. It was found useful against human constipation and improvement in digestion. It is used as a cooling food in summer (Maurya et al., 2015). A fresh Cucumber provides vitamin C, niacin, iron, calcium, thiamine, fibers and phosphorus (Khan et al., 2015). Besides, it is one of the very low-calorie vegetables; provide just 15 calories per $100 \mathrm{~g}$. It is an excellent source of potassium, an important intracellular electrolyte. $100 \mathrm{~g}$ of cucumber provides $147 \mathrm{mg}$ of potassium but only 2 $\mathrm{mg}$ of sodium. Cucumbers contain unique antioxidants in moderate ratios such as Bcarotene and $\alpha$-carotene, vitamin- $\mathrm{C}$, vitamin-K vitamin-A, zeaxanthin, and lutein. It helps in checking weight gain and high blood pressure. More than $50 \%$ production of Cucumber comes from Asia. Turkey, Iran, Uzbekistan, Japan and Iraq, were considered as leading Cucumber producing countries in Asia (Khan et al., 2015). In Bangladesh it is grown as a cash crop but the farmers of Comilla, Bogra, Rangpur, Noakhali, Faridpur, Chittagong and Mymensingh districts grow cucumber commercially. There is a scope for cultivation of cucumber in the cultivable land during summer season. It is profitable and its net return per hectare is relatively higher (Siful, 2008).

Modalities of such impact have been described in a good number of literatures. A modest attempt has been made here to review the previous research studies which are: Nahar, (2009) conducted a study in Jessore district and the major findings of the present study were that the year round vegetables production was profitable from the viewpoints of marginal, small, medium and large farmers. Bean, cabbage, cucumber and snake gourd were mainly produced in the study areas and per ha net returns of producing these crops were Tk. 89383, 90040, 90737.6 and 65473, respectively and undiscounted BCR came out to be 1.81, 1.87, 1.82 and 1.76 respectively which showed that vegetables production was profitable in the study area. The farmers 
tamed the highest profit from cucumber vegetables. Suraiya, (2008) made an economic analysis of some selected summer vegetables production in Purbadhala Upazila of Netrakona District. Per ha net returns of producing cucumber, okra, white gourd and snake gourd were Tk. 93452.0, 70380.0, 96896.0 and 58843.0 respectively. In other words, all the selected summer vegetables were highly profitable to their farmers. However, the farmers earned the highest profit from white gourd. Siful, (2008) found that cucumber is a profitable business in Mymensingh district. Gross returns per hectare for the corresponding categories of farmers were tk. $2525200,24500,240000$ and 245833.33 respectively. Per hectare yield of cucumber for small, medium, large and all farmers were 25250, 24500,2400 and $24583.33 \mathrm{~kg}$ respectively. Parvin, (2008) conducted an economic study of alternative rice and vegetables production in selected area of Mymensingh District. Boro rice, Aman rice, lady's finger, cabbage and white gourd were mainly produced in the study areas and per ha net returns of producing these crops were Tk. 23581, 3896, 86898, 89640 and 99000 , respectively. The farmers earned the highest profit from white gourd vegetables.

In the past, there was no exclusive study on the production and marketing of cucumber in Mymensingh. As such, it was felt that the study on the production of cucumber in some selected area of Mymensingh district would be of much importance. The findings of the study are likely to be helpful to the researchers and policy makers in the formulation of policies regarding efficient production and marketing system of cucumber in Bangladesh. The study may induce researchers to conduct further research in cucumber production. The current study aimed to assess the cost and return of cucumber production in addition to its marketing system in Mymensingh district of Bangladesh.

\section{MATERIALS AND METHODS}

The study was conducted in Phulpur upazilla and Mymensingh city from Mymesingh district where cucumber farmers were available. A total of 50 stakeholders where farmers were 30, wholesalers were 7, retailers were 7 and local traders were 6 in number who were interviewed using structured questionnaire for collection of data and information. Face-to-face interview method was conducted by the researcher.

\section{Analytical Technique \\ Profitability analysis}

Profitability of crop farming from the view point of individual farmer was measured in terms of gross return, gross margin, net return and benefit cost ratio (undiscounted). The formula need for the calculation of profitability is discussed below:

\section{Gross return (GR)}

Gross return was calculated by multiplying the total volume of output of an enterprise 
by the average price in the harvesting period (Dillon and Hardaker, 1993). The following equation was used to estimate GR:

$\mathrm{GR}=\mathrm{Y}_{\mathrm{m}} \mathrm{P}_{\mathrm{m}}+\mathrm{Y}_{\mathrm{b}} \mathrm{P}_{\mathrm{b}}$

Where,

$\mathrm{Y}_{\mathrm{m}}=$ Yield of main product per unit area;

$\mathrm{P}_{\mathrm{m}}=$ Price of main product;

$\mathrm{Y}_{\mathrm{b}}=$ Yield of by-product per unit area; and

$\mathrm{P}_{\mathrm{b}}=$ Price of by-product.

\section{Gross margin (GM)}

Gross margin was calculated by the difference between gross return and total variable costs.

That is,

$\mathrm{GM}=\mathrm{GR}-\mathrm{TVC}$

Where,

$\mathrm{GR}=$ Gross return; and

TVC $=$ Total variable cost .

\section{Net return (NR)}

Net return was calculated by deducting all costs (variable and fixed) from the gross return. To estimate the relative profitability of crops produced, profit equation of the following algebraic form was used:

$\mathrm{NR}=\mathrm{GR}-\mathrm{GC}$

Where,

$\mathrm{GR}=$ Gross return;

$\mathrm{GC}=$ Gross cost (i.e., TFC $+\mathrm{TVC}$ );

$\mathrm{TFC}=$ Total fixed cost per unit area; and

$\mathrm{TVC}=$ Total variable cost per unit area.

\section{Benefit cost ratio (BCR)}

A benefit cost ratio (BCR) is a relative measure which is used to compare the return per unit of cost. BCR was estimated as a ratio of gross return and gross cost. The formula of calculating BCR (undiscounted) is shown as below:

$\mathrm{BCR}=\mathrm{GR} \div \mathrm{GC}$

Where,

$\mathrm{GR}=$ Gross return; and

$\mathrm{GC}=$ Gross cost (i.e., TFC + TVC). 


\section{Marketing Margin}

Marketing margin has been calculated by using the following formulas (Ahmed, 2015):

Gross marketing margin $=$ Sale price -Purchase price

Net marketing margin $=$ Gross marketing margin - Marketing cost

Return on investment $(\%)=($ Net marketing margin/ Total investment $) \times 100$

Where, Total investment $=$ Purchase price + Marketing cost

\section{Ratio to moving average method}

Ratio to moving average method was applied in this study to measure the seasonal price variation of cucumber. Here, the original prices are expressed as percentage of the moving average. The 12-months moving average is a fairly good estimate of the trend and cyclical components combined. Therefore ratio to moving average provides an index of seasonal and irregular components combined because averaging this over years and adjustment through correction factor provides a better estimate of seasonal index (Acharya and Agarwal, 2001).

\section{RESULT AND DISCUSSION}

\section{Cost and Return of Cucumber Production}

For calculating total production cost, variable and fixed costs were taken into consideration. The components of variable cost were the cost of seed, fertilizers, irrigation, pesticides and human labour. Fixed cost items for crop production was land use cost (lease value of land) and interest on operating capital. Table 1 shows the cost of employing inputs in cucumber production. It is evident that total variable cost of cucumber production was tk.67129.72 per acre which was $92.18 \%$ of total cost. Total fixed cost was tk.5694.44 which was $7.81 \%$ of total cost. Total cost of cucumber production was tk.72824.16 per acre in the study area. In the study area, leasing cost of land is tk.1500 per katha ( 8 decimal) per year. Here land used cost of cucumber production was calculated for 3 months per acre and it was tk.4687.5 which accounted 6.43 per cent of the total cost. So we can see that the per acre cost of cucumber cultivation was about tk.72824.16 (Table 1). Analysis shows that the highest cost was for T.S.P (38.06\%) purpose. Other costs of farmer in descending manner were pesticides cost, urea cost, and human labour cost. Besides production cost, farmers had to spend for marketing purpose. Total cost of marketing of cucumber per kg was tk. 1.73. Of the total marketing cost, the highest share went to transportation $(57.80 \%)$. The obtained gross return, gross margin, net margin of cucumber production was tk. 115986.87, tk.48857.15 and tk. 43162.71per acre in the study area. Calculated BCR (Benefit cost ratio) was 1.59 which is greater than one; means cucumber cultivation was profitable (Table 1). Siful, (2008), in his economic analysis of cucumber production also found the same result. 
Table 1: Production cost, marketing cost and return of cucumber producing farmer

\begin{tabular}{|c|c|c|}
\hline \multicolumn{3}{|c|}{ Production cost } \\
\hline Particular & Amount (Tk./acre) & Percentage of total cost \\
\hline Labour Sowing/planting & 7048.39 & 9.67 \\
\hline Seed & 2152.96 & 2.95 \\
\hline Urea & 10023.08 & 13.76 \\
\hline TSP & 27720.36 & 38.06 \\
\hline MP & 3006.94 & 4.12 \\
\hline Cow-dung & 1966.85 & 2.70 \\
\hline Irrigation & 2711.11 & 3.72 \\
\hline Pesticides & 12500.00 & 17.16 \\
\hline Total variable cost & 67129.72 & 92.18 \\
\hline \multicolumn{3}{|l|}{ Fixed cost } \\
\hline Interest on operating capital & 1006.94 & 1.38 \\
\hline Land use cost (lease value of land) & 4687.5 & 6.43 \\
\hline Total fixed cost & 5694.44 & 7.81 \\
\hline Total cost & 72824.16 & 100 \\
\hline \multicolumn{3}{|c|}{ Marketing cost } \\
\hline Cost item & Amount (Tk./kg) & Percentage \\
\hline Transportation & 1.00 & 57.80 \\
\hline Market toll & 0.50 & 28.90 \\
\hline Telephone cost & 0.05 & 2.89 \\
\hline Personal expenses & 0.18 & 10.40 \\
\hline Total marketing cost & 1.73 & 100 \\
\hline \multicolumn{3}{|c|}{ Return of cucumber production } \\
\hline Particular & \multicolumn{2}{|c|}{ Amount } \\
\hline Production (kg/acre) & \multicolumn{2}{|c|}{8338.38} \\
\hline Price (Tk./kg) & \multicolumn{2}{|c|}{13.91} \\
\hline Gross return (Tk./acre) & \multicolumn{2}{|c|}{115986.87} \\
\hline Gross margin (Tk./acre) & \multicolumn{2}{|c|}{48857.15} \\
\hline Net margin (Tk./acre) & \multicolumn{2}{|c|}{43162.71} \\
\hline BCR(undiscounted) & \multicolumn{2}{|c|}{1.59} \\
\hline
\end{tabular}

Source: Field survey, 2017. 


\section{Marketing System of Cucumber}

\section{Marketing channels}

Two marketing channels of cucumber in Phulpur upazila and five channels from Mymensingh city were identified (Table 2).

Table 2: Marketing channels of cucumber in Phulpur and Mymensingh city

\begin{tabular}{ll}
\hline A: Marketing channel of cucumber in Phulpur \\
\hline Channel-I & Producer $\rightarrow$ Local traders $\rightarrow$ Wholesaler $\rightarrow$ Retailer $\rightarrow$ Consumer \\
Channel- II & Producer $\rightarrow$ Consumer \\
\hline \multicolumn{2}{l}{ B: Marketing channel of cucumber in Mymensingh city } \\
\hline Channel-I & Producer $\rightarrow$ Local trader $\rightarrow$ Wholesaler $\rightarrow$ Retailer $\rightarrow$ Consumer \\
Channel-II & Producer $\rightarrow$ Local trader $\rightarrow$ Retailer $\rightarrow$ Consumer \\
Channel-III & Producer $\rightarrow$ Retailer $\rightarrow$ Consumer \\
Channel-IV & Producer $\rightarrow$ Local trader $\rightarrow$ Consumer \\
Channel-V & Producer $\rightarrow$ Local trader $\rightarrow$ Retailer $\rightarrow$ Street seller $\rightarrow$ Consumer \\
\hline
\end{tabular}

Source: Field survey, 2017.

\section{Market Participants}

There were six market participants i.e. producer, local trader, wholesaler, retailer, street seller and consumer. The producers usually sold their cucumber to the local traders at the local market (Sosar bazar). Local traders were professional traders who purchased cucumber from producers at the local market. Purchased cucumber were packed those were consigned by truck to the wholesalers and retailers; who were located at the Mymensingh city. Wholesaler purchased cucumber from local traders and sold to the retailer. The retailers bought cucumber from local traders at farm level through wholesaler and sold those to the consumer and street seller. Sometimes they had no permanent shop, usually use open market place for selling cucumber. Most of the retailers had been doing business for more than ten years. The Street sellers were mainly school going boys and girls. They usually collected cucumber from retailer through wholesaler and sold them to the direct user in the busy roads of Mymensingh city. The consumers were the final buyers of cucumber. They purchased cucumber from the market place but sometimes they also purchased these from wholesale market and production area.

\section{Marketing functions}

\section{Buying, selling and handled volume of cucumber}

From producers to final users, price found to be changed many times and each time a new price was determined by the interaction of demand and supply. Pricing of cucumber was fixed by individual traders. The sellers reported that they did not 
follow any fixed price. The local traders at farm level purchased cucumber per $\mathrm{kg}$ at Tk. 12.11 and sold them at tk.16.17. On the other hand, wholesaler and retailer purchased cucumber at tk.15.50 and tk.17.93 respectively and sold them at tk.16.98 and tk.20.23 respectively. On an average a local trader, wholesaler and retailer handled respectively $200,500-800$ and 50-100 kg cucumber per day. The highest amount of cucumber was handled by the wholesalers followed by local trader and retailer (Table 3).

Table 3: Purchase, Sales and handled volume Price of Different Intermediaries

\begin{tabular}{l|c|c|c}
\hline $\begin{array}{l}\text { Type of } \\
\text { intermediaries }\end{array}$ & $\begin{array}{c}\text { Purchase price } \\
(\mathrm{Tk} . / \mathrm{kg})\end{array}$ & $\begin{array}{c}\text { Sales price } \\
(\mathrm{Tk} . / \mathrm{kg})\end{array}$ & $\begin{array}{c}\text { Handled volume } \\
(\mathrm{kg})\end{array}$ \\
\hline Local trader & 12.11 & 16.17 & $200 /$ day \\
Wholesaler & 15.50 & 17.93 & $500-800 /$ day \\
Retailer & 16.98 & 20.23 & $50-100 /$ day \\
\hline
\end{tabular}

Source: Field survey, 2017.

\section{Transportation, Financing and Market Information}

Farmers transported most of their product by van in the local market of Phulpur upazila, due to short distance $(3 \mathrm{~km})$ from the production site. The retailers of Mymensingh city used auto, van etc. for transportation.. The distance between Phulpur to Mymensingh city was $21 \mathrm{~km}$. Table 4, represents that $50 \%$ farmers were self-financed and $50 \%$ operated their business with own capital and borrowed from different NGOs. In case of local traders, $66.66 \%$ of them were self-financed and bank provided funds $33.33 \%$ to local traders. Almost all of the wholesaler were selffinanced $(71.42 \%)$ and others $(28.57 \%)$ were own sources and bank loan. Most of the retailers $(71.42 \%)$ were self-financed and other sources were bank loan $(28.57 \%)$. The main source of financing of cucumber trading was own capital. Most of the producer $(40 \%)$ received their market information from fellow traders. Local traders collected information through observation (50\%) and rest (50\%) from fellow traders. In case of wholesaler (71.42\%) information obtained over telephone or mobile. Most of the retailers $(71.42 \%)$ received their market information through visit to market and personal observation and information got from fellow traders $(28.57 \%)$ (Table 4$)$. 
Table 4: Mode of Transportation, Sources of Financing and Market Information Collection by Producers and Intermediaries

\begin{tabular}{|c|c|c|c|c|c|c|c|c|c|c|c|c|}
\hline \multirow{2}{*}{$\begin{array}{l}\text { Producers and } \\
\text { Intermediaries }\end{array}$} & \multicolumn{4}{|c|}{ Modes of transport } & \multicolumn{4}{|c|}{ Source of financing } & \multicolumn{4}{|c|}{ Source of information } \\
\hline & $\begin{array}{c}\text { Shoulder- } \\
\text { load }\end{array}$ & Auto & Van & Truck & Own & $\begin{array}{c}\text { Own }+ \\
\text { Bank loan }\end{array}$ & $\begin{array}{l}\text { Own + } \\
\text { NGO }\end{array}$ & Total & $\begin{array}{l}\text { Visit to market } \\
\text { and personal } \\
\text { observation }\end{array}$ & $\begin{array}{l}\text { Fellow } \\
\text { traders }\end{array}$ & $\begin{array}{c}\text { Neighbour } \\
\text { /friends }\end{array}$ & $\begin{array}{c}\text { Telephone } \\
\text { /mobile }\end{array}$ \\
\hline Producer & $\begin{array}{c}12 \\
(40.0 \%)\end{array}$ & $\begin{array}{c}0 \\
(0.0 \%)\end{array}$ & $\begin{array}{c}18 \\
(60.0 \%)\end{array}$ & $\begin{array}{c}0 \\
(0.0 \%)\end{array}$ & $\begin{array}{c}15 \\
(50 \%)\end{array}$ & $\begin{array}{c}0 \\
(0.0 \%)\end{array}$ & $\begin{array}{c}15 \\
(50 \%)\end{array}$ & $\begin{array}{c}30 \\
(100 \%)\end{array}$ & $\begin{array}{c}12 \\
(40 \%)\end{array}$ & $\begin{array}{c}12 \\
(40 \%)\end{array}$ & $\begin{array}{c}6 \\
(20 \%)\end{array}$ & $\begin{array}{c}0 \\
(0.0 \%)\end{array}$ \\
\hline Local trader & $\begin{array}{c}2 \\
(33.3 \%)\end{array}$ & $\begin{array}{c}4 \\
(66.6 \%)\end{array}$ & - & $\begin{array}{c}0 \\
(0.0 \%)\end{array}$ & $\begin{array}{c}4 \\
(66.66 \%)\end{array}$ & $\begin{array}{c}2 \\
(33.33 \%)\end{array}$ & $\begin{array}{c}0 \\
(0.0 \%)\end{array}$ & $\begin{array}{c}6 \\
(100 \%)\end{array}$ & $\begin{array}{c}3 \\
(50 \%)\end{array}$ & $\begin{array}{c}3 \\
(50 \%)\end{array}$ & $\begin{array}{c}0 \\
(0.0 \%)\end{array}$ & $\begin{array}{c}0 \\
(0.0 \%)\end{array}$ \\
\hline Wholesaler & - & $\begin{array}{c}1 \\
(14.28 \%)\end{array}$ & $\begin{array}{c}1 \\
(14.28 \%)\end{array}$ & $\begin{array}{c}5 \\
(71.42 \%)\end{array}$ & $\begin{array}{c}5 \\
(71.42 \%)\end{array}$ & $\begin{array}{c}2 \\
(28.57 \%)\end{array}$ & $\begin{array}{c}0 \\
(0.0 \%)\end{array}$ & $\begin{array}{c}7 \\
(100 \%)\end{array}$ & $\begin{array}{c}2 \\
(28.57 \%)\end{array}$ & $\begin{array}{c}0 \\
(0.0 \%)\end{array}$ & $\begin{array}{c}0 \\
(0.0 \%)\end{array}$ & $\begin{array}{c}5 \\
(71.42 \%)\end{array}$ \\
\hline Retailer & $\begin{array}{c}3 \\
(42.85 \%)\end{array}$ & $\begin{array}{c}4 \\
(57.14 \%)\end{array}$ & $\begin{array}{c}0 \\
(0.0 \%)\end{array}$ & $\begin{array}{c}0 \\
(0.0 \%)\end{array}$ & $\begin{array}{c}5 \\
(71.42 \%)\end{array}$ & $\begin{array}{c}2 \\
(28.57 \%)\end{array}$ & $\begin{array}{c}0 \\
(0.0 \%)\end{array}$ & $\begin{array}{c}7 \\
(100 \%)\end{array}$ & $\begin{array}{c}5 \\
(71.42 \%)\end{array}$ & $\begin{array}{c}2 \\
(28.57 \%)\end{array}$ & $\begin{array}{c}0 \\
(0.0 \%)\end{array}$ & $\begin{array}{c}0 \\
(0.0 \%)\end{array}$ \\
\hline Total & $\begin{array}{c}17 \\
(34 \%)\end{array}$ & $\begin{array}{c}9 \\
(18 \%)\end{array}$ & $\begin{array}{c}19 \\
(38 \%)\end{array}$ & $\begin{array}{c}5 \\
(10 \%)\end{array}$ & $\begin{array}{c}29 \\
(58 \%)\end{array}$ & $\begin{array}{c}6 \\
(12 \%)\end{array}$ & $\begin{array}{c}15 \\
(30 \%)\end{array}$ & $\begin{array}{c}50 \\
(100 \%)\end{array}$ & $\begin{array}{c}22 \\
(44 \%)\end{array}$ & $\begin{array}{c}17 \\
(34 \%)\end{array}$ & $\begin{array}{c}6 \\
(12 \%)\end{array}$ & $\begin{array}{c}5 \\
(10 \%)\end{array}$ \\
\hline
\end{tabular}

Source: Field survey, 2017. 


\section{Marketing Cost and Marketing margin by the Intermediaries}

Table 5 indicates that total marketing cost was tk. 6.16 per kg cucumber. Here total retailer cost was $25.59 \%$ of total marketing cost, wholesaler spent money $30.07 \%$ of total marketing cost and local traders share money $44.31 \%$ of total marketing cost. Shop rental cost was the highest cost (19.25\%). Next main costs in descending order were transport cost (16.24\%), electricity, market toll, assembling cost, and personal expenses. The table 6 also shows that average gross marketing margin was the highest for retailer $(4.23 \mathrm{Tk} . / \mathrm{kg})$ and lowest for wholesaler $(2.43 \mathrm{Tk} . / \mathrm{kg})$. Net marketing margin was highest for retailer $(2.65 \mathrm{tk} . / \mathrm{kg})$ and lowest for wholesaler $(0.58 \mathrm{tk} . / \mathrm{kg})$. While return on investment was highest for retailer $(14.27 \%)$ and lowest for wholesaler (3.34\%) (Table 5).

Table 5. Marketing Cost and Marketing Margin of Cucumber by Various Intermediaries

\begin{tabular}{|c|c|c|c|c|c|}
\hline \multicolumn{6}{|c|}{ Marketing Cost (Tk./ kg) } \\
\hline Cost items & Local traders & Wholesaler & Retailer & Cost & Percentage \\
\hline Assembling & 0.60 & - & - & 0.60 & 9.74 \\
\hline Transportation & 0.50 & 0.50 & - & 1.00 & 16.24 \\
\hline Shop rent & 0.44 & - & 0.75 & 1.19 & 19.25 \\
\hline Electricity & 0.28 & 0.45 & 0.37 & 1.10 & 17.88 \\
\hline Market toll & 0.25 & 0.25 & 0.25 & 0.75 & 12.18 \\
\hline Personal expenses & 0.47 & 0.45 & - & 0.92 & 14.97 \\
\hline Telephone & 0.20 & 0.20 & 0.20 & 0.60 & 9.74 \\
\hline Total & 2.73 & 1.85 & 1.57 & 6.16 & 100 \\
\hline Percentage $(\%)$ & 44.31 & 30.07 & 25.59 & 100 & \\
\hline \multicolumn{6}{|c|}{ Marketing Margin (Tk./kg) } \\
\hline Particular & \multicolumn{2}{|c|}{ Local traders } & \multicolumn{2}{|c|}{ Wholesaler } & Retailer \\
\hline Purchase price & \multicolumn{2}{|c|}{12.11} & \multicolumn{2}{|c|}{15.50} & 16.98 \\
\hline Sale price & \multicolumn{2}{|c|}{16.17} & \multicolumn{2}{|c|}{17.93} & 21.21 \\
\hline Gross marketing margin & \multicolumn{2}{|c|}{4.06} & \multicolumn{2}{|c|}{2.43} & 4.23 \\
\hline Marketing cost & \multicolumn{2}{|c|}{2.73} & \multicolumn{2}{|c|}{1.85} & 1.58 \\
\hline Net marketing margin & \multicolumn{2}{|c|}{1.33} & \multicolumn{2}{|c|}{0.58} & 2.65 \\
\hline Return on investment (\%) & \multicolumn{2}{|c|}{8.96} & \multicolumn{2}{|c|}{3.34} & 14.27 \\
\hline
\end{tabular}

Source: Field survey, 2017. 


\section{Seasonal Price Behavior of Cucumber}

As cucumber is perishable and cannot be stored for a long time, so cucumber producers and intermediaries want to sell their products as soon as possible. For this condition, when the production of cucumber increased then the price of cucumber decreased. The highest growers price index for cucumber was 135.67 found in the month of October, i.e., growers price of cucumber was $35.67 \%$ higher than the average growers price in this month and the lowest price index of growers was 60.62 in the month of May i.e., growers price was $39.38 \%$ lower than the average growers price in this month. After reaching the highest price in the month of October, then price declines till Month and then price rises. Since, seasonal growers price indices of cucumber was bigger in the month of September, October and November, so cucumber producers have to plan to cultivate in such a way so that they can harvest their cucumber in these months, then they will receive higher price. There is a big difference between highest and lowest price indices (135.67-60.62=75.05) (Table 6).

Table 6: Seasonal Price Index of Cucumber in Bangladesh

\begin{tabular}{l|l|l|l}
\hline \multicolumn{1}{c|}{ Month } & $\begin{array}{c}\text { Seasonal price } \\
\text { index }\end{array}$ & \multicolumn{1}{c}{ Highest value } & Lowest value \\
\hline January & 100.70 & & \\
February & 102.59 & & \\
March & 85.05 & & \\
April & 71.72 & 135.67 in the month of & Ma.62 in the month of \\
May & 60.62 & & \\
June & 67.87 & & \\
July & 91.68 & & \\
August & 117.23 & & \\
September & 135.42 & & \\
October & 135.67 & & \\
November & 117.43 & & \\
December & 114.02 & & \\
\hline
\end{tabular}

Source: Author's estimation, 2017.

Noonari, (2015) analyzed simple average seasonal index for onion and tomato in his study. The findings of the result was that for onion seasonal index was highest in November (221.75) and was lowest in January (65.95). On the other hand, for tomato it was highest in October (287.10) and was lowest in May (144.70). 


\section{CONCLUSION}

The findings of the study shows that in cucumber business gross and net marketing margin were higher for retailers than other intermediaries and they were local traders and wholesaler. For movement of cucumber from farmers to the consumers, a number of marketing channels were identified. The most common marketing function performed was buying and selling, transportation, packing, grading, financing and market information. The seasonal price indices of cucumber were the highest in the month of October and the lowest in the month of May. Production of cucumber was profitable with high gross returns. Some recommendations were suggested to improve the situation for cucumber production and marketing with a view to increase the income and employment opportunities of the cucumber farmers like lower price and good quality plant, low price of fertilizers and insecticides, access to scientific knowledge and training, reducing attack by pests and diseases, high market price, good environment, contact with extension work etc. If the modern production, harvesting and post-harvest technology can be made available to farmers and traders and performance of marketing system is to be improved, cucumber farming could be more viable and attractive to commercial enterprise which can improve their socioeconomic status and help in alleviating rural poverty in many areas of Bangladesh.

\section{REFERENCE}

Acharya, S.S., and Agarwal, N.L. (2001). Agricultural marketing in India .Oxford and IBH Publishing co., PVT., Ltd., New Delhi, pp.134.

Ahmed, J.U. (2015). Poor Farmers' Access to Milk Market for Sustainable Dairy Farming in Char Areas of Northern Bangladesh. Phd. Thesis. Department of Agricultural Economics. Bangladesh Agricultural University, Mymensingh.

BBS. (2014). Statistical Pocket Book of Bangladesh, Statistics Division, Ministry of Planning. Government of the People's Republic of Bangladesh. Dhaka.

Dillon, J.L., and Hardaker, J.B. (1993). Farm management research for small farmer development, FAO, Rome.

Khan, Z., Shah, A.H., Gul, R., Majid, A., Khan, U., and Ahmad, H. (2015). Morphoagronomic characterization of cucumber germplasm for yield and yield associated traits. International Journal of Agronomy and Agricultural Research 6: 1-6.

Maurya, G.P., Pal, V. Singh, G.P., and Meena, L.K. (2015). An economic analysis of cucumber cultivation in Sultanpur District of Uttar Pradesh (India). International Journal of Agricultural Science and Research 5: 23-28.

Nahar, (2009). An Economic analysis of year round vegetable production in Selected Area of Jessore District. M.S. Thesis. Department of Agricultural Economics. Bangladesh Agricultural University, Mymensingh.

Noonari, S., Irfana, N.M., Raiz, A.B., Muhammad, I.K., and Ali, S. (2015). Price Flexibility and Seasonal Variations of Major Vegetables in Sindh Pakistan. J Food Process Technol 6: 524. 
Parvin, M.S. (2008). An Economic Study of Alternative Rice and Vegetables Production in Selected Area of Mymensingh District. M.S. Thesis. Department of Agricultural Economics. Bangladesh Agricultural University, Mymensingh.

Siful, (2008). An Economic analysis of Cucumber cultivation in Selected Area of Mymensingh District. M. S. Thesis. Department of Agricultural Economics. Bangladesh Agricultural University, Mymensingh.

Suraiya, Z. (2008). An Economic Analysis of Some Selected Summer Vegetables Production in Purbadhala Upazila of Netrokona District. M.S. Thesis, Department of Agricultural Economics, Bangladesh Agricultural University, Mymensingh. 